\title{
TINGKAT KEBUDAYAAN
}

\author{
FANI NOVITA
}

\section{faninovita004@gmail.com}

\section{0}

\section{UNIVERSITAS EKA SAKTI AAI PADANG}

\section{A. PENDAHULUAN}

Budaya atau kebudayaan berasal dari bahasa Sanskerta yaitu buddhayah, yang merupakan bentuk jamak dari buddhi (budia atau akal) diartikan sebagai hal-hal yang berkaitan dengan budi, dan akal manusia. Bentuk lain dari kata budaya adalah kultur yang berasal dari bahasa Inggris yaitu culture dan bahasa Latin cultura.

kebudayaan adalah sesuatu yang akan memengaruhi tingkat pengetahuan, dan meliputi sistem ide atau gagasan yang terdapat dalam pikiran manusia, sehingga dalam kehidupan sehari-hari, kebudayaan itu bersifat abstrak.

Sedangkan perwujudan kebudayaan adalah benda-benda yang diciptakan oleh manusia sebagai makhluk yang berbudaya, berupa perilaku, dan benda-benda yang bersifat nyata, misalnya pola-pola perilaku, bahasa, peralatan hidup, organisasi sosial, religi, seni, dan lain-lain, yang semuanya ditujukan untuk membantu manusia dalam melangsungkan kehidupan bermasyarakat. Sebuah kebudayaan besar biasanya memiliki sub-kebudayaan (atau biasa disebut sub-kultur), yaitu sebuah kebudayaan yang memiliki sedikit perbedaan dalam hal perilaku, dan kepercayaan dari kebudayaan induknya. Munculnya sub-kultur disebabkan oleh beberapa hal, di antaranya karena perbedaan umur, ras, etnisitas, kelas, aesthetik, agama, pekerjaan, pandangan politik dan gender, 


\section{B. PEMBAHASAN}

Kebudayaan sangat erat hubungannya dengan masyarakat. Melville J. Herskovits dan Bronislaw Malinowski mengemukakan bahwa segala sesuatu yang terdapat dalam masyarakat ditentukan oleh kebudayaan yang dimiliki oleh masyarakat itu sendiri. Istilah untuk pendapat itu adalah Cultural-Determinism.

Herskovits memandang kebudayaan sebagai sesuatu yang turun temurun dari satu generasi ke generasi yang lain, yang kemudian disebut sebagai superorganic.

Menurut Andreas Eppink, kebudayaan mengandung keseluruhan pengertian nilai sosial, norma sosial, ilmu pengetahuan serta keseluruhan struktur-struktur sosial, religius, dan lain-lain, tambahan lagi segala pernyataan intelektual, dan artistik yang menjadi ciri khas suatu masyarakat.

Menurut Edward Burnett Tylor, kebudayaan merupakan keseluruhan yang kompleks, yang di dalamnya terkandung pengetahuan, kepercayaan, kesenian, moral, hukum, adat istiadat, dan kemampuan-kemampuan lain yang didapat seseorang sebagai anggota masyarakat.

Menurut Selo Soemardjan, dan Soelaiman Soemardi, kebudayaan adalah sarana hasil karya, rasa, dan cipta masyarakat.

Menurut M.Selamet Riyadi, Budaya adalah suatu bentuk rasa cinta dari nenek moyang kita yang diwariskan kepada seluruh keturunannya.

Menurut Koentjaraningrat kebudayaan adalah keseluruhan sistem gagasan, dan 
tindakan hasil karya manusia dalam rangka kehidupan masyarakat yang dimiliki manusia dengan belajar.

Dari berbagai definisi tersebut, dapat diperoleh pengertian bahwa kebudayaan adalah sesuatu yang akan memengaruhi tingkat pengetahuan, dan meliputi sistem ide atau gagasan yang terdapat dalam pikiran manusia, sehingga dalam kehidupan sehari-hari, kebudayaan itu bersifat abstrak.

Sedangkan perwujudan kebudayaan adalah benda-benda yang diciptakan oleh manusia sebagai makhluk yang berbudaya, berupa perilaku, dan benda-benda yang bersifat nyata, misalnya pola-pola perilaku, bahasa, peralatan hidup, organisasi sosial, religi, seni, dan lain-lain, yang semuanya ditujukan untuk membantu manusia dalam melangsungkan kehidupan bermasyarakat.

\section{Unsur Sunting}

Ada beberapa pendapat ahli yang mengemukakan mengenai komponen atau unsur kebudayaan, antara lain sebagai berikut:

Melville J. Herskovits menyebutkan kebudayaan memiliki 4 unsur pokok, yaitu:

alat-alat teknologi

sistem ekonomi

keluarga

kekuasaan politik

Bronislaw Malinowski mengatakan 4 unsur pokok kebudayaan meliputi:

sistem norma sosial yang memungkinkan kerja sama antara para anggota masyarakat untuk menyesuaikan diri dengan alam sekelilingnya

organisasi ekonomi

alat-alat, dan lembaga-lembaga atau petugas-petugas untuk pendidikan (keluarga adalah lembaga pendidikan utama)

organisasi kekuatan (politik) 
C. Kluckhohn mengemukakan ada 7 unsur kebudayaan secara universal (universal categories of culture) yaitu:

bahasa

sistem pengetahuan

sistem teknologi, dan peralatan

sistem kesenian

sistem mata pencarian hidup

sistem religi

sistem kekerabatan, dan organisasi kemasyarakatan

Wujud dan komponen Sunting

Wujud Sunting

Menurut J.J. Hoenigman, wujud kebudayaan dibedakan menjadi tiga: gagasan, aktivitas, dan artefak.

\section{Gagasan (Wujud ideal)}

Wujud ideal kebudayaan adalah kebudayaan yang berbentuk kumpulan ide-ide, gagasan, nilai-nilai, norma-norma, peraturan, dan sebagainya yang sifatnya abstrak yaitu tidak dapat diraba atau disentuh. Wujud kebudayaan ini terletak dalam pemikiran warga masyarakat. Jika masyarakat tersebut menyatakan gagasan mereka itu dalam bentuk tulisan, maka lokasi dari kebudayaan ideal itu berada dalam karangan, dan buku-buku hasil karya para penulis warga masyarakat tersebut.

Aktivitas (tindakan)

Aktivitas adalah wujud kebudayaan sebagai suatu tindakan berpola dari manusia dalam masyarakat itu. Wujud ini sering pula disebut dengan sistem sosial. Sistem sosial ini terdiri dari aktivitas-aktivitas manusia yang saling berinteraksi, mengadakan kontak, serta bergaul dengan manusia lainnya menurut pola-pola tertentu yang berdasarkan adat tata kelakuan. Sifatnya konkret, terjadi dalam kehidupan sehari-hari, dan dapat diamati, dan didokumentasikan.

Artefak (karya)

Artefak adalah wujud kebudayaan fisik yang berupa hasil dari aktivitas, perbuatan, 
dan karya semua manusia dalam masyarakat berupa benda-benda atau hal-hal yang dapat diraba, dilihat, dan didokumentasikan. Sifatnya paling konkret di antara ketiga wujud kebudayaan. Dalam kenyataan kehidupan bermasyarakat, antara wujud kebudayaan yang satu tidak bisa dipisahkan dari wujud kebudayaan yang lain. Sebagai contoh: wujud kebudayaan ideal mengatur, dan memberi arah kepada tindakan (aktivitas) dan karya (artefak) manusia.

Sedangkan menurut Koentjaraningrat, wujud kebudayaan dibagi menjadi nilai budaya, sistem budaya, sistem sosial, dan kebudayaan fisik.

\section{Nilai-nilai Budaya}

Istilah ini, merujuk kepada penyebutan unsur-unsur kebudayaan yang merupakan pusat dari semua unsur yang lain. Nilai-nilai kebudayaan yaitu gagasan-gagasan yang telah dipelajari oleh warga sejak usia dini, sehingga sukar diubah. Gagasan inilah yang kemudian menghasilkan berbagai benda yang diciptakan oleh manusia berdasarkan nilai-nilai, pikiran, dan tingkah lakunya.

Sistem Budaya

Dalam wujud ini, kebudayaan bersifat abstrak sehingga hanya dapat diketahui dan dipahami. Kebudayaan dalam wujud ini juga berpola dan berdasarkan sistem-sistem tertentu.

\section{Sistem Sosial}

Sistem sosial merupakan pola-pola tingkah laku manusia yang menggambarkan wujud tingkah laku manusia yang dilakukan berdasarkan sistem. Kebudayaan dalam wujud ini bersifat konkret sehingga dapat diabadikan.

Kebudayaan Fisik

Kebudayaan fisik ini merupakan wujud terbesar dan juga bersifat konkret. Misalnya bangunan megah seperti candi Borobudur, benda-benda bergerak seperti kapal tangki, komputer, piring, gelas, kancing baju, dan lain-lain.

Komponen Sunting

Berdasarkan wujudnya tersebut, kebudayaan memiliki beberapa elemen atau komponen, menurut ahli antropologi Cateora, yaitu: 
Kebudayaan material

Kebudayaan material mengacu pada semua ciptaan masyarakat yang nyata, konkret. Termasuk dalam kebudayaan material ini adalah temuan-temuan yang dihasilkan dari suatu penggalian arkeologi: mangkuk tanah liat, perhisalan, senjata, dan seterusnya. Kebudayaan material juga mencakup barang-barang, seperti televisi, pesawat terbang, stadion olahraga, pakaian, gedung pencakar langit, dan mesin cuci.

Kebudayaan nonmaterial

Kebudayaan nonmaterial adalah ciptaan-ciptaan abstrak yang diwariskan dari generasi ke generasi, misalnya berupa dongeng, cerita rakyat, dan lagu atau tarian tradisional. Lembaga sosial

Lembaga sosial dan pendidikan memberikan peran banyak dalam konteks berhubungan dan berkomunikasi di alam masyarakat. Sistem sosial yang terbentuk dalam suatu negara akan menjadi dasar dan konsep yang berlaku pada tatanan sosial masyarakat. Contoh di Indonesia pada kota, dan desa di beberapa wilayah, wanita tidak perlu sekolah yang tinggi apalagi bekerja pada suatu instansi atau perusahaan. Tetapi di kota - kota besar hal tersebut terbalik, wajar jika seorang wanita memiliki karier.

Sistem kepercayaan

Bagaimana masyarakat mengembangkan, dan membangun sistem kepercayaan atau keyakinan terhadap sesuatu akan memengaruhi sistem penilaian yang ada dalam masyarakat. Sistem kepercayaan ini akan memengaruhi kebiasaan, pandangan hidup, cara makan, sampai dengan cara berkomunikasi.

\section{Estetika}

Berhubungan dengan seni dan kesenian, musik, cerita, dongeng, hikayat, drama, dan tari-tarian, yang berlaku, dan berkembang dalam masyarakat. Seperti di Indonesia setiap masyarakatnya memiliki nilai estetika sendiri. Nilai estetika ini perlu dipahami dalam segala peran agar pesan yang akan disampaikan dapat mencapai tujuan dan efektif. Misalkan di beberapa wilayah, dan bersifat kedaerahan, setiap akan membangun bangunan jenis apa saja harus meletakkan janur kuning, dan buah- 
buahan sebagai simbol, di mana simbol tersebut memiliki arti berbeda di setiap daerah. Tetapi di kota besar seperti Jakarta jarang, mungkin, terlihat masyarakatnya menggunakan cara tersebut.

\section{Bahasa}

Bahasa merupakan alat pengantar dalam berkomunikasi, bahasa untuk setiap wilayah, bagian, dan negara memiliki perbedaan yang sangat kompleks. Dalam ilmu komunikasi bahasa merupakan komponen komunikasi yang sulit dipahami. Bahasa memiliki sifat unik dan kompleks yang hanya dapat dimengerti oleh pengguna bahasa tersebut. Jadi keunikan, dan kekompleksan bahasa ini harus dipelajari, dan dipahami agar komunikasi lebih baik serta efektif dengan memperoleh nilai empati dan simpati dari orang lain.

\section{PENUTUP}

Sebuah kebudayaan besar biasanya memiliki sub-kebudayaan (atau biasa disebut sub-kultur), yaitu sebuah kebudayaan yang memiliki sedikit perbedaan dalam hal perilaku, dan kepercayaan dari kebudayaan induknya. Munculnya sub-kultur disebabkan oleh beberapa hal, di antaranya karena perbedaan umur, ras, etnisitas, kelas, aesthetik, agama, pekerjaan, pandangan politik dan gender,

Ada beberapa cara yang dilakukan masyarakat ketika berhadapan dengan imigran, dan kebudayaan yang berbeda dengan kebudayaan asli. Cara yang dipilih masyarakat tergantung pada seberapa besar perbedaan kebudayaan induk dengan kebudayaan minoritas, seberapa banyak imigran yang datang, watak dari penduduk asli, keefektifan, dan keintensifan komunikasi antar budaya, dan tipe pemerintahan yang berkuasa. 


\section{DAFTAR PUSTAKA}

Gokma Toni Parlindungan S, Asas Nebis In Idem Dalam Putusan Hakim Dalam Perkara Poligami Di Pengadilan Negeri Pasaman Sebagai Ceriminan Ius Constitutum, Volume 2, Nomor 1, 2020.

Gokma Toni Parlindungan S, Pengisian Jabatan Perangkat Nagari Pemekaran Di Pasaman Barat Dalam Rangka Pelaksanaan Otonomi Daerah, Ensiklopedia Of Journal, Vol 1 No 2 Edisi 2 Januari 2019,

Harniwati, Peralihan Hak Ulayat Menurut Undang-Undang Nomor 18 Tahun 2004, Volume 1, Nomor 3, 2019.

Jasmir, Pengembalian Status Hukum Tanah Ulayat Atas Hak Guna Usaha, Soumatera Law Review, Volume 1, Nomor 1, 2018.

Jumrawarsi Jumrawarsi, Neviyarni Suhaili, Peran Seorang Guru Dalam Menciptakan Lingkungan Belajar Yang Kondusif, Ensikopedia Education Review, Vol 2, No 3 (2020): Volume 2 No.3 Desember 2020

Mia Siratni, Proses Perkawinan Menurut Hukum Adatdi Kepulauan Mentawai Di Sebelum Dan Sesudah Berlakunya Undang-Undang Nomor 1 Tahun 1974 Tentang Perkawinan, Ensiklopedia Of Journal, Vol 1 No 2 Edisi 2 Januari 2019, 
Remincel, Dimensi Hukum Pelanggaran Kecelakaan Lalu Dan Angkutan Jalan Lintas Di Indonesia, Ensiklopedia Social Review, Volume 1, Nomor 2, 2019.

R Amin, B Nurdin, Konflik Perwakafan Tanah Muhammadiyah di Nagari Singkarak Kabupaten Solok Indonesia 2015-2019, Soumatera Law Review, Volume 3, Nomor 1, 2020. 